\title{
Biological Monitoring of Chlorpyrifos Exposure to Rice Farmers in Vietnam
}

\author{
Dung Tri Phung ${ }^{\mathrm{a},{ }^{*}}$, Des Connell ${ }^{\mathrm{b} *}$, Greg Miller $^{\mathrm{a}}$, Mary Hodge ${ }^{\mathrm{b}}$, Renu Patel $^{\mathrm{b}}$, Ron Cheng ${ }^{\mathrm{b}}$, \\ Manel Abeyewardene ${ }^{b}$, Cordia $\mathrm{Chu}^{\mathrm{a}}$ \\ ${ }^{\mathrm{a} C e n t r e}$ for Environment and Population Health, Griffith School of Environment, Griffith University, 170 Kessel \\ Road, Nathan, QLD 4111, Australia. \\ ${ }^{\mathrm{b}}$ Griffith School of Environment, Griffith University, 170 Kessel Road, Nathan, QLD 4111, Australia. \\ ${ }^{\mathrm{c}}$ Queensland Health Forensic and Scientific Service, Kessel Road, Coopers Plains, QLD 4108, Australia. \\ *Corresponding author: Dung T Phung, tel.+61413816293, fax:+61(07)37355318, email: \\ ptdzung70@yahoo.com; OR, Des Connell, tel.: +61(07)37354082, fax:+61(07)37356717, email: \\ d.connell@griffith.edu.au
}

\section{Introduction}

Chlorpyrifos is a commonly used anticholinesterase organophosphate insecticide. It was introduced into the market in 1965 and used for both agricultural and non-agricultural purposes (ATSDR, 1997a). A major use of chlorpyrifos is for crop protection on farms cultivating fruit, vegetables and grains and to control insect pests in the home (e.g., cockroaches, fleas, and termites). Chlorpyrifos is considered to have a high potential for adverse effects in occupational applications (Aponso, 2002).

The primary target organ for chlorpyrifos toxicity is the central and peripheral nervous systems, since its metabolite, chlorpyrifos-oxon is an acetylcholinesterese inhibitor, this may cause death and have adverse sub-lethal effects in humans. Low-level exposure to chlorpyrifos has caused interference with the development of the mammalian nervous system during pregnancy (Slotkin et al., 2006). Developmental effects such as low birth weight and reduced head circumference were found in human epidemiological studies on pregnant women exposed to chlorpyrifos (Whyatt and Barr, 2004). Chlorpyrifos is also considered to be an endocrine disrupting compound (Rawling et al., 1998). Although there is insufficient evidence of carcinogenicity, some recent studies have shown an association between 
chlorpyrifos exposure and both lung and prostate cancer (Alavanja et al., 2003, Lee et al., 2004).

Agricultural activities are considered a primary source of exposure to chlorpyrifos (Alexander et al., 2006, Curwin et al., 2007). In developing countries, small-scale farmers were found to have a high risk of adverse health effects from chlorpyrifos when mixing, loading and spraying chlorpyrifos using back-pack sprayers (Rodriguez et al., 2006, Panuwet et al., 2008, Aponso, 2002).

Vietnam has approximately 80 per cent of workers employed in agriculture (Hung, 2003), mainly rice farming. Farmers are at high risk of pesticide exposure due to the use of back-pack reservoirs for pesticide application, low safety knowledge, and limited use of personal protection equipment (Dung, 2006). Chlorpyrifos is the most common organophosphate insecticide registered for agricultural use in Vietnam (MARD, 2009). However, the exposure assessment and evaluation of adverse health effects of chlorpyrifos with these farmers has not been evaluated.

Urinary 3,5,6-trichloropyridinol (TCP), is a major metabolite of chlorpyrifos (Figure 1) in humans (Nolan et al., 1984a) and has been used to evaluate chlorpyrifos exposure (Chang et al., 1996, Hunter et al., 1999, Aprea et al., 1999). Several analytical methods have been developed to analyse chlorpyrifos and TCP in biological fluids (Aprea et al., 1999, Kawashaki et al., 1992, Bartels and Kastl, 1992, Brzak et al., 1998), usually by liquid-liquid extraction, followed by gas chromatography with mass spectrometric detection (GC-MS). Alternatively, the combination of liquid chromatography and tandem mass spectrometry (LCMS) allows direct analysis of TCP in prepared urine extracts without derivatisation (Sancho et al., 2000). However, the extraction of urine results in the presence of substances which interfere with the LCMS analysis. 
Enzyme, $\beta$-glucuronidase type H-1 (500 units/mg), Sigma, USA is a product of glucuronidation, conjugation with glucuronic acid, by the human UDPglucuronosyltransferase (UGT) family of enzymes which plays a key role in the metabolic fate of drugs and other xenobiotics. This biosynthetic reaction is also involved in the conjugation and excretion of endogenous substrates, including steroids, bilirubin, and bile acids. The conjugation between glucuronic acid and substrates which contain sulfhydryl, hydroxyl, aromatic amino, or carboxylic acids moieties forms glucuronides which are more water soluble than the parent organic substrate and are generally excreted via the kidney

The objective of this study was to measure chlorpyirifos exposure in Vietnamese rice farmers, who are pesticide applicators, using TCP analysis following an enzymatic treatment of urine and extraction in order to remove glucuronide and sulphate-bound conjugates which interfere with the analysis (Curwina et al., 2010). Using the results of the TCP analysis the exposure to chlorpyrifos would be calculated, and the level of health risk to the Vietnamese farmers evaluated.

\section{Materials and Methods}

\subsection{Samples of human urine}

The study area was a typical agricultural commune ( $\mathrm{Vu}$ Le commune) in North Vietnam. Urine samples (108) were collected during 2009 from Vietnamese rice farmers (18) using plastic containers (2 litre); sub-samples were transferred into HDPE plastic bottles. Each farmer contributed 6 samples at different periods related to pesticide application, comprising: one sample within a week pre-application, one sample on the application day, and 4 samples within the week post-application. The samples were frozen within 4 hours of collection and stored at $-20^{\circ} \mathrm{C}$ before analysis. 


\subsection{Analysis of TCP in urine}

\subsubsection{Principle of the method}

The samples of human urine were hydrolysed using enzyme, $\beta$-glucuronidase type $\mathrm{H}-1$, solvent extracted using methyl-tert-butyl-ether (MTBE)/hexane (30\%), followed by concentration of extracts and analysis by liquid chromatography/mass spectrometry (LC/MS). For each batch of urine samples analysed, the reagent blank, a control sample, spiked samples, and a set of matrix standards with concentrations from $50-500 \mu \mathrm{g} / \mathrm{L}$ were also processed and analysed. TCP level of the control urine sample was used to correct and check \% recovery of the spiked sample.

\subsubsection{Glassware and chemicals}

All glass equipment was rinsed with acetone before use and dried at room temperature. Deionized water was purified by the Hi-Pure Water System (Permutit Australia). All chemicals used were Analytical Grade or higher purity: Acetonitrile (99.8\%) (Mallincrkrodt Chemicals, USA), sodium sulphate (10-60 mesh) (Mallincrodt Barker Inc., Mexico), sodium hydroxide used to prepare 0.25M NaOH (Biolab Ltd., Australia), acetone (99.8\%) (Merck, Germany), hexane (95\% n-hexane) (J.T.Baker, USA), sodium acetate (BDH Chemicals, Australia), methyl tert-butyl ether (MTBE) used to prepare 30\% MTBE/hexane (Merck, Germany), hydrochloric acid 32\% used to prepare 0.5M HCL (Ajax Finechem, Australia), and TCP reference standard $(99.4 \% \pm 0.5 \%)$ (ChemService, USA).

\subsubsection{Stability trials of urinary TCP}

The influence of temperature and storage time was investigated. The control urine was spiked with $56.5 \mu \mathrm{g}$ TCP/L, and samples were taken for urinary TCP stability trials evaluating storage time and temperature as follows: at $-18^{\circ} \mathrm{C}$ (freezer condition), room temperature $\left(20^{\circ} \mathrm{C}\right)$ and $4^{\circ} \mathrm{C}$ (refrigerator condition). 


\subsubsection{Standard preparation}

TCP reference standard was made up as $92.6 \mathrm{mg} / \mathrm{L}$ stock solution for spiking and a $95.6 \mathrm{mg} / \mathrm{L}$ stock soluation for standard preparation. Further dilutions of the stock solutions were made with acetonitrile to prepare final working standards with concentrations of 50, 100, 200 , and $500 \mu \mathrm{g} / \mathrm{L}$. The standards were analysed by the method below to prepare calibration curves for each batch of urine samples. Control urine was used to prepare the matrix standards, and these were processed in the same way as original urine samples until the evaporation phase.

\subsubsection{Sample preparation and extraction}

A subsample of urine $(2 \mathrm{ml})$ was removed from each urine sample for analysis and processed in batches of samples (24). Each batch of samples comprised: a reagent blank, control urine, spiked sample, matrix standards, and urine samples from farmers (17). The spiked samples were prepared by adding $200 \mu \mathrm{L}$ of TCP standard $(100 \mu \mathrm{g} / \mathrm{L} \mathrm{TCP})$ using a $500 \mu \mathrm{L}$ syringe.

Enzyme, $\beta$-glucuronidase type $\mathrm{H}-1$, was added to each sample. The enzyme, equivalent to 800 units of activity, was dissolved in $0.2 \mathrm{M}$ acetate buffer. The buffer was prepared by dissolving $9.7 \mathrm{~g}$ of sodium acetate in $3.1 \mathrm{ml}$ of glacial acetic acid and making it up to $1000 \mathrm{ml}$ with deionised water. $1.5 \mathrm{ml}$ of the dissolved enzyme was added to each sample. The samples were incubated for 17 hours at $37^{\circ} \mathrm{C}$, then extracted by the following steps: (1) deionised water $(6.5 \mathrm{ml})$ was added and vortexed; (2) saturated $\mathrm{Na}_{2} \mathrm{SO}_{4}(1 \mathrm{ml})$ was added and vortexed; (3) $\mathrm{pH}$ was adjusted to $\mathrm{d} 2$ by adding 4 drops of concentrated HCL acid; (4) samples were extracted with 30\% MTBE/hexane (2ml); (5) shaking for 2 minutes followed by centrifuging at $3200 \mathrm{rpm}$ for 8 minutes (repeated 3 times); (6) the organic phase from the extractions were bulked; (7) $0.25 \mathrm{M} \mathrm{NaOH}(3 \mathrm{ml})$ was added and shaken; (8) saturated $\mathrm{Na}_{2} \mathrm{SO}_{4}$ (1 ml) was added and hand shaken for 2 minutes, then the aqueous phase was retained; (9) the aqueous phase was adjusted to $\mathrm{pH} 2$ by adding $4 \mathrm{ml}$ of $0.5 \mathrm{HCl}$ acid; (10) re-extraction as per 
Steps 4-5 for three times without centrifuging, and bulking the organic phase; (11) samples were then evaporated to $\sim 1 \mathrm{ml}$ and matrix standards to just dryness; (12) for samples, acetonitrile (400 uL) was added to samples and the hexane layer evaporated, (13) for matrix standards, relevant amounts of $1 \mathrm{mg} / \mathrm{L} \mathrm{TCP}$ standards was added to make a series of standards ranging from $0-500 \mu \mathrm{g} / \mathrm{L}$ with final volume of $400 \mu \mathrm{L}$ in acetonitrile. All samples and matrix standards were then transferred into screw cap vials for HPLC-MS/MS.

\subsubsection{The type of enzyme}

Enzyme, $\beta$-glucuronidase type H-1 (500 units/mg), Sigma, USA is a product of glucuronidation, conjugation with glucuronic acid, by the human UDPglucuronosyltransferase (UGT) family of enzymes which plays a key role in the metabolic fate of drugs and other xenobiotics. This biosynthetic reaction is also involved in the conjugation and excretion of endogenous substrates, including steroids, bilirubin, and bile acids. The conjugation between glucuronic acid and substrates which contain sulfhydryl, hydroxyl, aromatic amino, or carboxylic acids moieties forms glucuronides which are more water soluble than the parent organic substrate and are generally excreted via the kidney. The enzyme $\beta$-glucuronidase catalysis is expressed by the following general reaction:

$$
\beta \text {-D-glucuronoside }+\mathrm{H}_{2} \mathrm{O} \leftrightarrow \text { an alcohol }+ \text { D-glucuronate }
$$

The $\beta$-glucuronidase type $\mathrm{H}-1$ is used for a variety of purposes, such as: enzymatic hydrolysis of the metabolites from urine, plasma, serum, or bile prior to analyses and digestion of fungal mycelium. $\beta$-glucuronidase type $\mathrm{H}-1$ from Helix pomatia is a partially purified, essential saltfree powder of enzymes descended from the Roman snail (SIGMA, 2004).

\subsubsection{Liquid chromatography/mass spectrometry (HPLC-MS/MS) condition}

TCP in urine extracts were determined by HPLC-MS/MS using an AB/Sciex

API4000Q mass spectrometer (AB/Sciex Concord, Canada) equipped with an electrospray (TurboV) interface coupled to a Shimadzu Prominence HPLC system (Shimadzu, Japan). 
Separation was achieved using a 5 micron $150 x 4.6 \mathrm{~mm}$ Alltima $\mathrm{C}_{18}$ column (Alltech, Australia) run at $40^{\circ} \mathrm{C}$, and a flow rate of $0.8 \mathrm{ml}$ per minute. The mobile phase consisted of A $=1 \% \mathrm{MeOH} / 99 \% \mathrm{HPLC}$ grade water $/ 0.1 \%$ acetic acid, $\mathrm{B}=95 \% \mathrm{MeOH} / 5 \% \mathrm{HPLC}$ grade water $/ 0.1 \%$ acetic acid. The solvent mixture was maintained at $65 \% \mathrm{~B}$ for 15 minutes. Injection volume was $15 \mu \mathrm{L}$. Positive samples were confirmed by retention time and by comparing transition intensity ratios between the sample and an appropriate concentration standard from the same run. Samples were only reported as positive if two transitions were present, retention times within 0.15 minutes of the standard and the relative intensity of the confirmation transition is within $20 \%$ of the expected value.

\subsubsection{Calculation of TCP concentration}

The TCP $(\mu \mathrm{g} / \mathrm{L})$ concentration from HPLC-MS/MS was calculated using the regression equations from the standard curve obtained with each bathch of samples (Figure 2). These results were corrected for control urine by subtracting the TCP level of the control urine, then correction with the recovery percentage of the spiked sample. The standard curve, control urine, and spiked sample were analysed with every batch of samples. The limit of detection (LOD was estimated as three times the standard deviation calculated from 11 values of the lowest calibration standards $(50 \mu \mathrm{g} / \mathrm{L})$, and the limit of reporting (LOR) was estimated as nine times the standard deviation.

\subsubsection{Quality control (QC) of analytical runs}

Quality control was carried out using duplicate samples (every 20 samples), spiked samples (one per process batch), repeat samples (one per batch), and reagent blank sample (one deionised water per batch). The spiked samples were analysed before and during the analysis of all batches of farmer's samples. 


\subsection{Analysis of Creatinine in urine}

Creatinine is a by-product of creatinin that is an important component of muscle tissue, and its rate of production depends on individual's muscle mass or lean body weight, which varyies with age, gender, for each given individual. The pesticides and metabolites are usually adjusted by urinary creatinine concentrations; these "creatinine-corrected" concentrations are presented in $\mu \mathrm{g} / \mathrm{g}$ creatinine (Barr et al., 2005). In this study, 24-hour urine samples were collected from farmers and stored cold $\left(2-4^{\circ} \mathrm{C}\right)$, and sent to Thai Binh Medical University, Vietnam. The samples were analysed for creatinine by the method of an automated colorimetric determination based on a modified Jaffe reaction, using a Bayer Express Plus Chemistry Analyser (ELITECH, 2005).

\subsection{Estimation of chlorpyrifos Absorbed Daily Dose (ADD) from urinary TCP}

The estimation of chlorpyrifos Absorbed Daily Dose (ADD) used the approach described by Mage et al., 2004 and Curwin et al, 2007, in which the ADD in microgram of pesticide per kilogram body weight per day $(\mu \mathrm{g} / \mathrm{kg} /$ day) was calculated from a combination of individual urinary metabolite concentration and individual daily creatinine excretion rate $(\mathrm{g} / \mathrm{d})$ calculated from their age, gender, height and weight of the exposed individual, on a body weight basis. The equation used to estimate ADD of the pesticide is described below:

$$
\mathrm{ADD}=\mathrm{C} . \mathrm{Cn} \cdot \mathrm{CF} \cdot \mathrm{R}_{\mathrm{mw}} / \mathrm{BW}
$$

\section{Equation 1}

where, ADD is Absorbed Daily Dose $(\mu \mathrm{g} / \mathrm{kg} / \mathrm{d}) ; \mathrm{C}$ is concentration of metabolite or pesticide in urine per gram creatinine ( $\mu \mathrm{g} / \mathrm{g}$ creatinine); $\mathrm{Cn}$, calculated mass of creatinine excreted per day (g/day); CF, correction factor of chlorpyrifos $=1.4$ (approximately $70 \%$ is excreted as TCP in urine); $\mathrm{R}_{\mathrm{mw}}$, the ratio of parent pesticide and pesticide metabolite molecular weights; BW, body weight $(\mathrm{kg})$.

TCP $(\mu \mathrm{g} / \mathrm{L})$ concentration in urine was converted to creatinine adjusted TCP $(\mu \mathrm{g} / \mathrm{g}$ creatinine). The total concentration of TCP ( $\mathrm{C}$ in Equation 1) was calculated as the sum of 
TCP found in urine above the baseline, application-day, and from 24 to 120 hours postapplication (Table 1). Finally, chlorpyrifos Absorbed Daily Dose (ADD) was estimated using Equation 1.

A comparison of the ADD level observed in this study with that reported from previous studies was made, using ADD levels which were recalculated from the values of TCP reported by using Equation 1. Where $\mathrm{C}$ was the median value of TCP reported in the study, and the values of age, body weight and height were taken either from the same studies or from US EPA Exposure Factor HandBook (US EPA, 1997). The average creatinine in urine was $0.5 \mathrm{~g} / \mathrm{L}$ (Medlineplus), and other factors, comprising $\mathrm{CF}$ and $\mathrm{R}_{\mathrm{mw}}$ were the same as described above.

\section{Results and discussion}

\subsection{Characteristics of participant farmers}

The characteristics of the participant farmers are shown in Table 1. The age ranged from 19 to 59 years (mean: $42.6 \pm 2.7$ ), comprising 13 male and 5 female farmers. Almost all the participants had an educational level at the secondary school level (13/18 farmers), and their main occupation was as a farmer. Average weight and height of participants were $53 \pm 1.3$ $\mathrm{kg}$ and $162 \pm 1.7 \mathrm{~cm}$ respectively. The health status of the participants was good based on selfreporting and health examination by the district medical centre.

The farmer households own small-scale rice farms with areas from 1620 to $4320 \mathrm{~m}^{2}$ (mean: $3100 \pm 155 \mathrm{~m}^{2}$ ). The farmers had an average of 23 years experience working in rice cultivation with agricultural pesticide application, including two young farmers having 4-year working experience. The amount of chlorpyrifos active ingredient used was from $54-144 \mathrm{~g}$ (mean: $104 \pm 5 \mathrm{~g}$ ). Depending on the areas to be sprayed and personal ability, the number of application hours varied from 3 to 7.5 hours (mean: $5.2 \pm 0.3$ hours). All farmers had no standard occupational protective equipment, but most wore a normal hat, masks or face- 
covers, long-sleeve shirts and pants. The percent of body surface areas of farmers covered by protective equipment ranged from about 65 to $85 \%$ (mean: $80 \pm 1.6 \%$ ).

\subsection{Characterization of the analytical method}

A typical calibration curve based on standard solutions with TCP concentration levels from $50-500 \mu \mathrm{g} / \mathrm{L}$ of urine is shown in Figure1. Statistical analyses indicated high linearity, with typical correlation coefficients of approximate 0.99 . A typical equation is shown below:

$$
\mathrm{C}_{\mathrm{TCP}}=0.904 \mathrm{~A}+38
$$

Equation 2

where, $\mathrm{C}_{\mathrm{TCP}}$ is concentration of TCP in urine ( $\mu \mathrm{g} / \mathrm{g}$ creatinine); $\mathrm{A}$, area ( $\left.\mu \mathrm{V} . \mathrm{s}\right)$.

The limit of detection (LOD) was estimated to be $0.6 \mu \mathrm{g} / \mathrm{L}$, and the LOR was determined at approximately $2 \mu \mathrm{g} / \mathrm{L}$. This result was lower than the value of detection limits reported using a similar analytical method coupled with GCMS (4-6 $\mu \mathrm{g} / \mathrm{L})$ in the similar study conducted on Sri-Lanka farmers (Aponso, 2002). However, it was essentially the same as the values reported in previous studies using a similar method coupled with LC-MS/MS which reported the LOD at $0.5 \mu \mathrm{g} / \mathrm{L}$ (Sancho et al., 2000) and at $0.4 \mu \mathrm{g} / \mathrm{L}$ (Ander et al., 2004).

Spiked samples were analysed before and during the analysis of all batches of participant's samples. The recovery values were from 80 to $114 \%$, with an average of $95.8 \%$. This result was comparable with the recovery of urinary TCP reported in previous investigations (Sancho et al., 2000, Aponso, 2002) which ranged from 87-114\%. The results of duplicate sample analysis indicated the relative percentage difference (RPD) ranged from $7 \%$ to $27 \%$. The RPD of repeated samples ranged from 5 to $13 \%$. These are all in acceptable levels for precision. Moreover, The TCP concentration of 8 reagent blank samples was found below the LOD in all.

\subsection{Stability of TCP in human urine}

Urinary TCP was recovered at levels of $64 \%$ to $112 \%$ when stored at room temperature $\left(25^{\circ} \mathrm{C}\right), 71 \%$ to $110 \%$ at $3{ }^{\circ} \mathrm{C}$, and $72 \%$ to $112 \%$ at minus $20^{\circ} \mathrm{C}$ over 74 hours. A comparison 
of these values for recovery of TCP indicated no significant differences among groups of samples related to the storage temperatures (T-test of comparison for two pairs of means: room- and fridge-temperature group, and room- and freezer-temperature group, $\mathrm{p}_{\text {value }}=0.2$ and 0.5).

\subsection{Levels of TCP observed in human urine}

A total of 120 urine samples were collected (6 samples per farmer) during the pesticide application event in Vietnam. Baseline values of the urine TCP of farmers, which were obtained over 7 days prior to pesticide application, were from $0.7-14.7 \mu \mathrm{g} / \mathrm{g}$ creatinine (mean $2.8 \pm 0.8 \mu \mathrm{g} \mathrm{TCP} / \mathrm{g}$ creatinine). The mean of urinary TCP levels was highest at 24 hours after pesticide application $(47.5 \pm 12.8 \mu \mathrm{g} \mathrm{TCP} / \mathrm{g}$ creatinine $)$ and returned to the baseline value at 144 hours (the $6^{\text {th }}$ day) after application (see Figure 3). All individual farmers had the same pattern of urinary TCP levels as related to the time of application. The total TCP excreted among individual farmers ranged widely from 3-678 $\mu \mathrm{g} \mathrm{TCP} / \mathrm{g}$ creatinine (mean: $173 \pm 43 \mu \mathrm{g}$ $\mathrm{TCP} / \mathrm{g}$ creatinine).

The median level of urinary TCP observed after application with Vietnamese farmers (127 $\mu \mathrm{g} \mathrm{TCP} / \mathrm{g}$ creatinine) was lower than that with farmers in other developing countries such as Sri-Lanka median $175 \mu \mathrm{g}$ TCP/g creatinine (Aponso, 2002) and Nicaragua median $243 \mu \mathrm{g}$ $\mathrm{TCP} / \mathrm{g}$ creatinine (Rodriguez et al., 2006). However, this level was higher than that of USA farmers who had median of $28 \mu \mathrm{g}$ TCP/g creatinine (Alexander et al., 2006). The exposure levels resulting from agricultural applications were generally lower than that among termiticide applicators (median $319 \mu \mathrm{g} \mathrm{TCP} / \mathrm{g}$ creatinine)(Cynthia and James, 2001) and industrial workers (median $650 \mu \mathrm{g}$ TCP/g creatinine) (Burns et al., 2006).

\subsection{Chlorpyrifos ADD estimated from urinary TCP}

Chlorpyrifos ADD estimated from the post-application urinary TCP of farmers, using Equation 1 is presented in the Table 2. Post-application chlorpyrifos ADD of farmers varied 
from $0.4-94.2 \mu \mathrm{g} / \mathrm{kg} / \mathrm{d}$ with a mean of $19.4 \mu \mathrm{g} / \mathrm{kg} / \mathrm{d}$. This was approximately 80 -fold higher than the mean baseline exposure level $(0.24 \mu \mathrm{g} / \mathrm{kg} / \mathrm{d})$. The Absorbed Daily Dose (ADD) is the actual amount of chlorpyrifos absorbed into the human body after exposure to chlorpyrifos from different pathways, usually consisting of oral ingestion, inhalation, and dermal absorption. Nolan et al. (1984) estimated that at least $70 \%$ of chlorpyrifos was absorbed and recovered in the urine following a single oral dose, and $1.28 \pm 0.75 \%$ of an applied dose through dermal absorption is recovered in the urine after 24h (Nolan et al.,1984b). Dermal absorption was estimated at $1 \%$ in another study (Griffin et al., 1999). Although there was no direct measurement estimating chlorpyrifos absorption after inhalation exposure, this substance was generally considered to be well absorbed into the body through the lungs (Geer et al., 2004).

The guidelines are described by the term: acute reference dose, aRfD(NPIC, 2009, NRA, 2000) or minimal risk level, MRL (ATSDR, 1997b); however, these values were estimated by similar procedure using NOEL or NOAEL and application of a Safety Factor. The acute guidelines recommended from the agencies varies from $3-10 \mu \mathrm{g} / \mathrm{kg} / \mathrm{d}$ due to use of different endpoint bases for standards and different safety factor. US EPA used the NOEL causing plasma cholinesterase inhibition in rat $(500 \mu \mathrm{g} / \mathrm{kg})$ and a Safety Factor of 100 (Cleveland et al., 2001); whereas, ATSDR used the endpoint of neurological effect (30 $\mu \mathrm{g} / \mathrm{kg})$ in human volunteers and the Safety Factor of 10. The Australian NRA used NOEL (100 $\mu \mathrm{g} / \mathrm{kg})$ causing plasma BuChE inhibition in humans and a Safety Factor of 10 while the joint meeting WHO/FAO recommended high NOEL $(1,000 \mu \mathrm{g} / \mathrm{kg})$ which caused RBC AChE inhibition in humans and a Safety Factor of 10 (Cleveland et al., 2001).

In relation to characteristics of farmers, the mean ADD of male farmers $(20.6 \mu \mathrm{g} / \mathrm{kg} / \mathrm{d})$ was higher than that of female farmers $(17.5 \mu \mathrm{g} / \mathrm{kg} / \mathrm{d})$, but the difference was not statistically significant (p-value, 0.8). However, the ADD (4.9 $\mu \mathrm{g} / \mathrm{kg} / \mathrm{d}$ ) found with higher educated 
farmers (high school and college) was significantly lower than that $(25.4 \mu \mathrm{g} / \mathrm{kg} / \mathrm{d})$ with farmers with secondary school level (p-value, 0.02). With continuous factors, the ADD was highly correlated with the amount of chlorpyrifos active ingredient used (correlation coefficient $r, 0.7)$, percent of body area covered by personal protective equipment $(r,-0.85)$, length of application (r, 0.7). The ADD levels were medium and weakly correlated with working experience in rice cultivation and pesticide application $(r, 0.5)$, age $(r, 0.4)$, and BMI $(\mathrm{r}, 0.4)$.

The Hazard Quotient (HQ) using the minimum, mean, and maximum values of chlorpyrifos exposure (ADD) with participant farmers are presented in Table 3. The HQs at the maximum values range from 9.4-31.4 indicating much higher exposure than guidelines recommended by these agencies (US EPA, ATSDR, and Australian NRA). However, the maximum HQ of 0.9 indicated lower exposure than the acute guideline developed by WHO/FAO. Similarly, the HQs at mean values range from 2.1-6.9 which indicates that the exposure levels exceeded the acute guidelines recommended by national agencies (US EPA, ATSDR, and NRA). The HQs at minimum values (0.04-0.13) indicate that exposure is lower than guidelines recommended by all agencies.

A comparison of chlorpyrifos ADD values reported from previous studies and those observed in this study is presented in Figure 4. The median exposure value observed with Vietnamese rice farmers $(8 \mu \mathrm{g} / \mathrm{kg} / \mathrm{d})$ was higher than that found among Sri-Lanka farmers $(5.3 \mu \mathrm{g} / \mathrm{kg} / \mathrm{d})$ (Aponso, 2002), but lower than that observed in Nicaragua farmers (18.7 $\mu \mathrm{g} / \mathrm{kg} / \mathrm{d}$ ) (Rodriguez et al., 2006). The possible reasons for these differences are different farming activities by participant farmers recruited in the studies with some being fruit farmers other than rice farmers, also differences can be attributed to: (i) sampling methods during the application day (void urines versus 24-hour urine), (ii) analytical procedure (normal extraction versus enzymatic pre-treatment extraction), and (iii) ADD estimated from TCP 
(90\% absorption in Sri-Lanka study versus $70 \%$ absorption in Vietnamese and Nicaragua studies).

Overall, the median exposure levels of chlorpyrifos for farmers in developing countries (Vietnam, Sri-Lanka and Nicaragua) were higher than that for USA farmers $(2.5 \mu \mathrm{g} / \mathrm{kg} / \mathrm{d})$ (Alexander et al., 2006). This might be explained by differences in the pesticide application method that is back-pack spraying commonly used by farmers in developing countries versus mechanical application methods such as truck or aerial sprays by farmers in USA. However all of these median levels were lower than that found for US termiticide workers $(21.7 \mu \mathrm{g} / \mathrm{kg} / \mathrm{d})$ (Cynthia and James, 2001) and manufacturer workers $(53.2 \mu \mathrm{g} / \mathrm{kg} / \mathrm{d})($ Burns et al., 2006). This may be due to different intensity of chlorpyrifos exposure. The termiticide workers and manufacturing workers exposed to chlorpyrifos regularly during daily work while farmers are exposed to chlorpyrifos by application events for a few seasonal crops a year.

\section{Conclusions}

This study showed that enzymatic pre-treatment before extraction for measuring the urinary metabolite TCP by HPLC-MS/MS was an effective method for biological monitoring of chlorpyrifos exposure in agricultural farmers. For instance, the LOD of urinary TCP analysis $(0.6 \mu \mathrm{g} / \mathrm{L})$ was lower than that reported in some similar previous studies and fell in the range of the results recently reported using an improved analytical method for TCP (0.4$0.6 \mu \mathrm{g} / \mathrm{L})$. This method of biological monitoring evaluates the internal dose of chlorpyrifos resulting from all exposure pathways, comprising inhalation, dermal and ingestion. The absorbed daily dose of chlorpyrifos (ADD) can be calculated from urinary TCP which can be compared to acute exposure guidelines for chlorpyrifos.

The case study with Vietnamese rice farmers illustrated that the farmers had a relatively high exposure to chlorpyrifos after an application event. The exposure levels were highly associated with some factors, comprising educational levels of farmers, the amount of 
chlorpyrifos active ingredient used, length of application, percent of body area covered by personal protective equipment. The mean Hazard Quotient with Vietnamese rice farmers ranged from 2.1 to 6.9 using the acute reference doses recommended by United States and Australian agencies; however, this value was still lower than $1(0.2)$ using the acute reference dose developed by FAO/WHO. These results suggest adverse health effects, resulting primarily from neurological effects caused by chlorpyrifos-oxon metabolite are likely occur with rice farmers in Vietnam.

\section{Ethical clearance}

This study was approved for ethical clearance by Griffith University Human Research Committee (HREC) and issued with authorisation to be commenced from 14/04/2009 (SU Protocol Number ENV/04/09/HERC).

\section{Funding}

This work was supported by Australian Endeavour Post Graduate Award (scholarship for doctoral study); Griffith School of Environment (additional funding for research higher degree students); and in-kind contribution of Emeritus Professor Des Connell.

\section{Acknowledgment}

The authors are grateful to colleagues at General Department of Preventive Medicine and Environment, Vietnam Ministry of Health; Thai Binh Preventive Medicine Centre; Kien Xuong District Medical Centre; Vu Le Commune Health Clinic; and Thai Binh Medical University for valuable support and assistance in the sampling program. 


\section{References}

ALAVANJA, C. R., SAMANIC, C., DOSEMECIL, M., LUBIN, J., TARONE, R., LYNCH, C. F., KNOTT, C., THOMAS, K., HOPPIN, J. A., BARKER, J., COBLE, J., SNADLER, D. P. \& BLAIR, A. 2003. Use of Agricultural Pesticides and Protate Cancer Risk in the Agricultural Health Study Cohort. Am J of Epidem, 157, 800-814.

ALEXANDER, B. H., BURNS, C. J., BARTELS, M. J., AQUAVELLA, J. F., MADEL, K. S., GUSTIN, C. \& BAKER, B. A. 2006. Chlorpyrifos Exposure in Farm Families: Results from the Farm Family Exposure Study. Journal of Exposure Science and Environmental Epidemiology, 16, 447-456.

ANDER, O. O., SAMUEL, E. B., JOHNNY, V. N., LOVISA, C. R., SIMEON, O. U., ROBERT, D. W., KATHRYN, L. F. \& BARR, D. 2004. A Liquid Chromatography-tandem Mass Spectrometry Multiresidue Method for Quantification of Specific Metbolites of Organophosphorous Pesticides, Synthetic Pyrethoids, Slected Herbicides, and DEET in Human Urine Urine. Anal. Chem. , 76, 2453-2461.

APONSO, M. L. 2002. Exposure and Risk Assessment for Farmers Occupationally Exposed to Chlorpyrifos. Annals of the Sri Lanka Department of Agriculture, 4, 233-244.

APREA, C., BETTA, A., CATENACCI, G., LOTTI, A., MAGNAGHI, S., BARISANO, A., PASSINI, V., PAVAN, I., SCIARRA, G., VITALONE, V. \& MINOIA, C. 1999. Reference values of urinary 3,5,6-trichloro-2pyridinol in the Italian population--validation of analytical method and preliminary results (multicentric study). J AOAC Int., 82, 305-312.

ATSDR 1997a. Toxicological Profile for Chlorpyrifos. In: Registry, A. F. T. S. A. D. (ed.). Atlanta, GA.

ATSDR 1997b. Toxicological Profile for Chlorpyrifos. U.S.Department of Health and Human Services, Agency for Toxic Substances and Disease Registry, Public Health Service: Atlanta, 1997.

BARR, D. B., WILDER, L. C., CAUDILL, S. P., GONZALEZ, A. J., NEEDHAM, L. L. \& PIRKLE, J. L. 2005. Urinary Creatinine Concentrations in the U.S. Population: Implications for Urinary Biologic Monitoring Measurements. Envi. Health Persp., 113, 192-200.

BARTELS, M. J. \& KASTL, P. E. 1992. Analysis of 3,5,6-trichloropyridinol in human urine using negativeion chemical ionization gas chromatography-mass spectrometry J Chromatogr. , 575, 69-74.

BRZAK, K. A., HARMS, D. W., BARTELS, R. J. \& NOLAN, R. J. 1998. Determination of chlorpyrifos, chlorpyrifos oxon and 3,5,6-trichloro-2-pyridinol in rat and human blood. J. Anal. Toxicol., 22, 203-210.

BURNS, C. J., GARABRANT, D., ALBERS, J. W., BERENT, S., GIORDANI, B., HAIDAR, S., GARRISON, R. \& RICHARDSON, R. J. 2006. Chlorpyrifos exposure and biological monitoring among manufacturing workers. . Occup Environ Med, 63, 218-220.

CHANG, M. J. W., LIN, C. Y., LO, L. W. \& LIN, R. S. 1996. Biological of Exposure to Chlorpyrifos by High Perfomance Liquid Chromatography. Bull. Environ. Contam. Toxicol., 56, 367-374.

CLEVELAND, C. B., OLIVER, G. R., CHEN, B. \& MATTSSON, J. 2001. Risk Assessment under FQPA: Case Study with Chlorpyrifos. NeuroToxicology 22, 699-706.

CURWIN, B. D., HEIN, M. T., SANDERSON, W. T., STRILEY, C., HEEDERIL, D., KROMHOUT, H., REYNOLDS, S. J. \& ALAVANJA, M. C. 2007. Pesticide Dose Estimates for Children of lowa Farmers and Non-Farmers. Environmental Research, 105, 307-315.

CURWINA, B. D., HEINA, M. J., BARRB, D. B. \& STRILEYC, C. 2010. Comparison of immunoassay and HPLC-MS/MS used to measure urinary metabolites of atrazine, metolachlor, and chlorpyrifos from farmers and non-farmers in lowa. Journal of Exposure Science and Environmental Epidemiology. , 20, 205-212.

CYNTHIA, J. H. \& JAMES, A. D. 2001. Determinant of chlorpyrifos exposure and urinary 3,5,6trichloro-2-pyridinol levels among termiticide applicators. Ann.Occup. Hyg., 45, 309-321.

DASGUPTA, S., MEISNER, C., WHEELER, D., XUYEN, K. \& LAM, N. T. 2007. Pesticide poisoning of farm workers-implications of blood test results from Vietnam. Int. J. Hyg. Environ.-Health, 210, 121-132.

DUNG, N. H. 2006. The Case of Farmers in Rice Production in the Mekong Delta Vietnam. SubRegional Conference on Proverty Environment Nexus - LAO PDR. 
ELITECH. 2005. RE: Creatinine Jaffe.

FAO/WHO 1999. Pesticide Residues in Food, Report 153, Chlorpyrifos. World Health Organization, Geneva, Switzerland.

GEER, L. A., CARDELLO, N., DELLARCO, M. J., LEIGHTON, T. J., ZENDZIAN, R. P., ROBERT, J. D. \& BUCKLEY, T. J. 2004. Comparative analysis of passive dosimetry and biomonitoring for assessing chlorpyrifos exposure in pesticide workers. Ann. Occup. Hyg., 48, 683-695.

GRIFFIN, P., MASON, H., HEYWOOD, K. \& COCKER, J. 1999. Oral and dermal absorption of chlorpyrifos: A human volunteer study. J. Occ. Environ. Med., 56, 10-13.

HUNG, H. T., DU, N. T. \& HOJER, J. 2008. The First Poison Control Center in Vietnam: Experiences of Its Initial Years. Southeast Asian Journal of Tropical Medicine and Public Health, 39, 310-317.

HUNG, L. M. 2003. Economic Characteristics of Population of Vietnam. 2003 Population Census Conference. Kyoto, Japan.

HUNTER, D. L., LASSITER, T. L. \& PADILLA, S. 1999. Gestational exposure to chlorpyrifos: comparative distribution of trichloropyridinol in the fetus and dam. Toxicol. Appl. Pharmacol., 158, 16-23.

KAWASHAKI, S., UEDA, H., ITOH, H. \& TADANO, J. 1992. Screening of organophosphorus pesticides using liquid chromatography-atmospheric pressure chemical ionization mass spectrometry. J Chromatogr., 595, 193-202.

LEE, W. J., BLAIR, A., HOPPIN, J. A., RUSIECKI, J. A., SANDLER, D. P., DOSEMECI, M. \& ALAVANJA, M. C. 2004. Cancer Incidence among Pesticide Applicators Exposed to Chlorpyrifos in the Agricultural Health Study. J Natl Cancer Inst., 96, 457-465.

MARD 2009. The registration list of pesticides in Vietnam in 2009.

NOLAN, R. J., RICK, D. L., FRESHOUR, N. L. \& SAUNDERS, J. H. 1984a. Chlorpyrifos: Pharmacokinetics in Human Volunteers. Toxicol. Appl. Pharmacol., 73, 8-15.

NOLAN, R. J., RICK, D. L., FRESHOUR, N. L. \& SAUNDERS, J. H. 1984b. Chlorpyrifos: pharmacokinetics in human volunteers. Toxicol. Appl. Pharmacol., 73, 8-15.

NPIC 2009. Chlorpyrifos Technical Fact Sheet. .

NRA 2000. National Registration Authority. NRA review of chlorpyrifos. Canberra.

PANUWET, P., PRAPAMONTOL, T., CHANTARA, S. \& BARR, D. B. 2008. Concentration of Urinary Pesticide Metabolites in Small-scale Farmers in Chiang Mai Province, Thailan. Science of The Total Environment, 407, 655-668.

RAWLING, N. C., COOK, S. J. \& WALDBILLIG, D. 1998. Effects of the Pesticides Carbofuran, Chlorpyrifos, Dimethoate, Lindane, Triallate, Trifluralin, 2,4-D, and Pentachlorophenol on the Metabolic Endocrine and Reproductive Endocrine System in Ewes. J Tox. Envi. Health, 54, 2136.

RODRIGUEZ, T., YOUNGLOVE, L., LU, C., FUNEZ, A., WEPPNER, S., BARR, D. \& FENSKE, A. R. 2006. Biological Monitoring of Pesticide Exposures among Applicators and Their children in Nicaragua. Int J Occup Environ Health, 12, 312-320.

SANCHO, J. V., POZO, O. J. \& HERNA'DEZ, F. L. 2000. Direct Determination of Chlorpyrifos and Its Main Metabolite 3,5,6-trichloro-2-pyridinol in Human Serum and Urine by Coupled-column Liquid Chromatography/Electrospray-tandem Mass Spectrometry. Rpid Commun. Mass. Spectrom., 1485-1490

SIGMA 2004. Production Information.

SLOTKIN, T. A., LEVIN, E. D. \& SEIDLER, F. J. 2006. Comparative Development Neurotoxicity of Organophosphate Insecticides: Effects on Brain Development Are Separable from Systematic Toxicity. Env. Health Persp., 114, 746-751.

US EPA 1997. Exposure Factor Handbook, National Center for Environmnetal Assessment. Office of Research and Development.

WHO/FAO 1999. Pesticide Residues in Food, Report 153, Chlorpyrifos. World Health Organization, Geneva, Switzerland.

WHYATT, R. M. \& BARR, D. B. 2004. Prenatal Insecticide Exposures and Birth Weight and Length among an Urban Minority Cohort. Env. Health Persp., 112, 1125-1132. 
Table 1 Characteristics of rice cultivation and chlorpyrifos application of participant farmers

\begin{tabular}{|c|c|}
\hline Chracteristics & Value \\
\hline \multicolumn{2}{|l|}{ Age } \\
\hline Mean (range) & $42.6(19-59)$ year olds \\
\hline \multicolumn{2}{|l|}{ Gender } \\
\hline Male & 13 \\
\hline Female & 8 \\
\hline \multicolumn{2}{|l|}{ Educational level } \\
\hline Secondary school & 13 \\
\hline High school & 4 \\
\hline College & 1 \\
\hline \multicolumn{2}{|l|}{ Body Mass Index (BMI) } \\
\hline Mean (range) & $20.2(16.6-24.7)$ \\
\hline \multicolumn{2}{|l|}{ Area of rice farm } \\
\hline Mean (range) & $3,100(1,620-4,320) \mathrm{m}^{2}$ \\
\hline \multicolumn{2}{|c|}{$\begin{array}{l}\text { Working experience in rice cultivation } \\
\text { and pesticide application }\end{array}$} \\
\hline Mean (range) & $23(4-40)$ years \\
\hline \multicolumn{2}{|c|}{$\begin{array}{l}\text { Amount of chlorpyrifos active ingredient } \\
\text { used }\end{array}$} \\
\hline Mean (range) & 104 (54-144) grams \\
\hline \multicolumn{2}{|c|}{ Length of chlorpyrios application } \\
\hline \multicolumn{2}{|c|}{$\begin{array}{l}\text { Body coverage by personal protective } \\
\text { equipment }\end{array}$} \\
\hline Mean (range) & $80 \%(63.5-84.8)$ \\
\hline
\end{tabular}

*Estimated based on: the percentage of body surface areas reported by Graber (1997), personal protective equipment reported by participant farmers, and the table used for body coverage estimation among farmers during chlorpyrifos application in the thesis of Aponso (2002). 
Table 2 Chlorpyrifos Absorbed Daily Dose (ADD) estimated from total urinary TCP*

\begin{tabular}{|c|c|c|c|c|c|c|c|c|c|}
\hline \multirow[t]{2}{*}{ Farmer } & \multicolumn{8}{|c|}{ Urinary TCP $(\mu \mathrm{g} / \mathrm{g}$ Creatinine $)$} & \multirow{2}{*}{$\begin{array}{c}\text { ADD } \\
(\mu \mathrm{g} / \mathrm{kg} / \mathrm{d})\end{array}$} \\
\hline & Baseline & Application-day & 24 hour & 48 hour & 72 hour & 96 hour & 120 hour & Total & \\
\hline F1 & 0.82 & 29.90 & 73.7 & 61.2 & 46.1 & 37.5 & 29.7 & 279 & 37.3 \\
\hline $\mathbf{F} 2$ & 1.84 & 1.57 & 2.2 & 3.4 & 2.4 & 2.1 & 2.0 & 16 & 1.9 \\
\hline $\mathbf{F 3}$ & 0.78 & 19.90 & 35.7 & 26.2 & 24.8 & 15.2 & 7.7 & 130 & 8.7 \\
\hline $\mathbf{F 4}$ & 3.48 & 7.12 & 12.6 & 12.9 & 11.2 & 9.2 & 13.9 & 70 & 5.4 \\
\hline F5 & 1.17 & 25.10 & 46.1 & 37.9 & 27.7 & 15.4 & 11.5 & 165 & 19.8 \\
\hline F6 & 0.68 & 14.40 & 28.7 & 26.8 & 20.7 & 18.5 & 25.2 & 135 & 13.7 \\
\hline F7 & 0.67 & 34.10 & 182.0 & 108.0 & 95.1 & 56.7 & 27.1 & 504 & 51.6 \\
\hline F8 & 1.65 & 35.20 & 57.0 & 48.1 & 47.6 & 25.8 & 0.3 & 215 & 24.7 \\
\hline F9 & 0.76 & 3.65 & 5.1 & 4.7 & 3.0 & 1.0 & 0.6 & 19 & 1.7 \\
\hline F10 & 3.76 & 97.40 & 173.0 & 148.0 & 135.0 & 85.0 & 34.9 & 678 & 94.2 \\
\hline F11 & 5.27 & 3.64 & 12.9 & 9.5 & 8.6 & 7.5 & 3.6 & 51 & 6.3 \\
\hline F12 & 3.52 & 1.74 & 4.4 & 3.2 & 4.3 & 5.2 & 7.0 & 29 & 1.7 \\
\hline F13 & 1.21 & 24.50 & 35.7 & 26.1 & 15.3 & 14.6 & 7.4 & 125 & 7.9 \\
\hline F14 & 14.7 & 62.10 & 98.4 & 76.7 & 52.7 & 39.9 & 22.5 & 367 & 49.4 \\
\hline F15 & 4.00 & 4.91 & 19.2 & 15.2 & 9.5 & 8.4 & 2.5 & 64 & 7.8 \\
\hline F16 & 2.15 & 28.40 & 48.6 & 36.4 & 36.9 & 24.4 & 16.9 & 194 & 15.3 \\
\hline F17 & 2.00 & 19.80 & 19.1 & 17.9 & 9.0 & 0.3 & 1.0 & 69 & 7.4 \\
\hline F18 & 1.26 & 0.70 & 0.1 & 0.45 & 0.0 & 0.2 & 0.2 & 3 & 0.4 \\
\hline
\end{tabular}


Table 3 Hazard Quotient with minimum, mean, and maximum value of chlorpyrifos exposure among rice farmers

\begin{tabular}{|c|c|c|c|}
\hline \multicolumn{3}{|l|}{ Acute Guideline } & HQ maximum \\
\hline \multicolumn{4}{|l|}{ US EPA } \\
\hline $5 \mu \mathrm{g} / \mathrm{kg} / \mathrm{d}$ & 0.08 & 4.2 & 18.8 \\
\hline \multicolumn{4}{|l|}{ ATSDR } \\
\hline $3 \mu \mathrm{g} / \mathrm{kg} / \mathrm{d}$ & 0.13 & 6.9 & 31.4 \\
\hline \multicolumn{4}{|c|}{ Australian NRA } \\
\hline $10 \mu \mathrm{g} / \mathrm{kg} / \mathrm{d}$ & 0.04 & 2.1 & 9.4 \\
\hline \multicolumn{4}{|l|}{ WHO/FAO } \\
\hline $100 \mu \mathrm{g} / \mathrm{kg} / \mathrm{d}$ & 0.004 & 0.2 & 0.9 \\
\hline
\end{tabular}



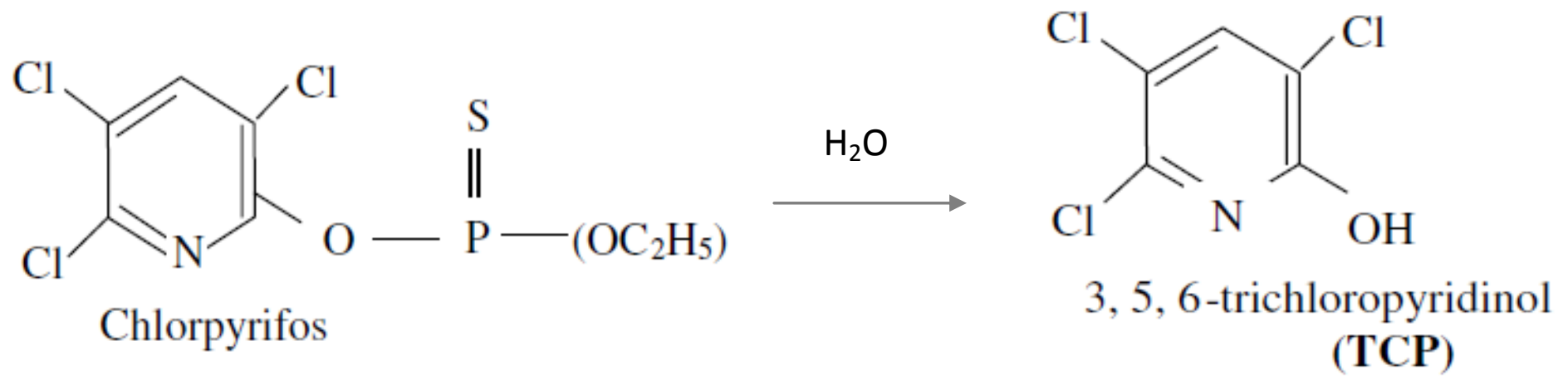

Fig.1. Hydrolysis of Chlorpyrifos to give 3,5,6-trichloropyridinol (TCP) 


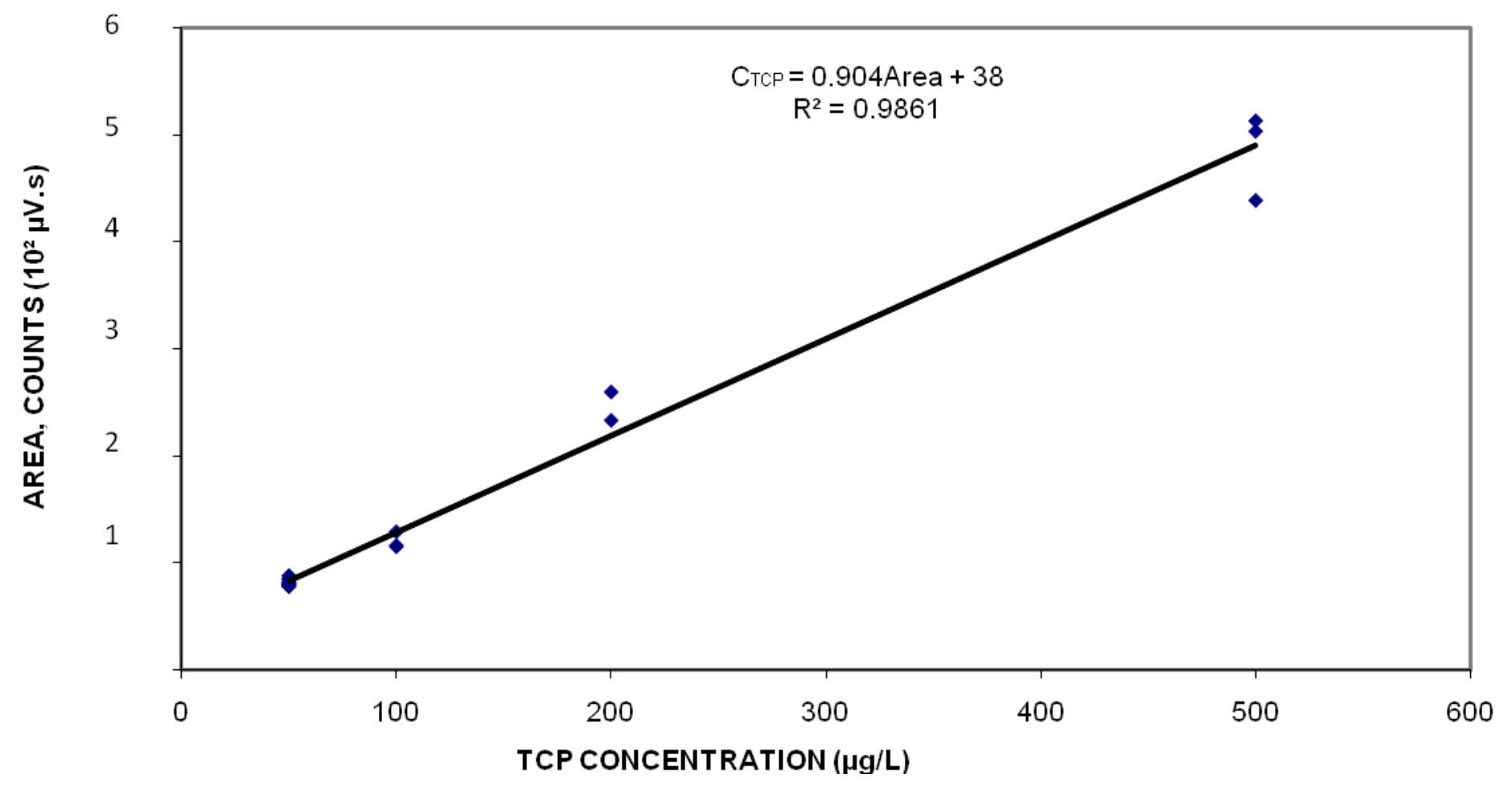

Fig.2. A typical calibration for the plot of the standard TCP solutions against the area of the peaks produced with LCMS 


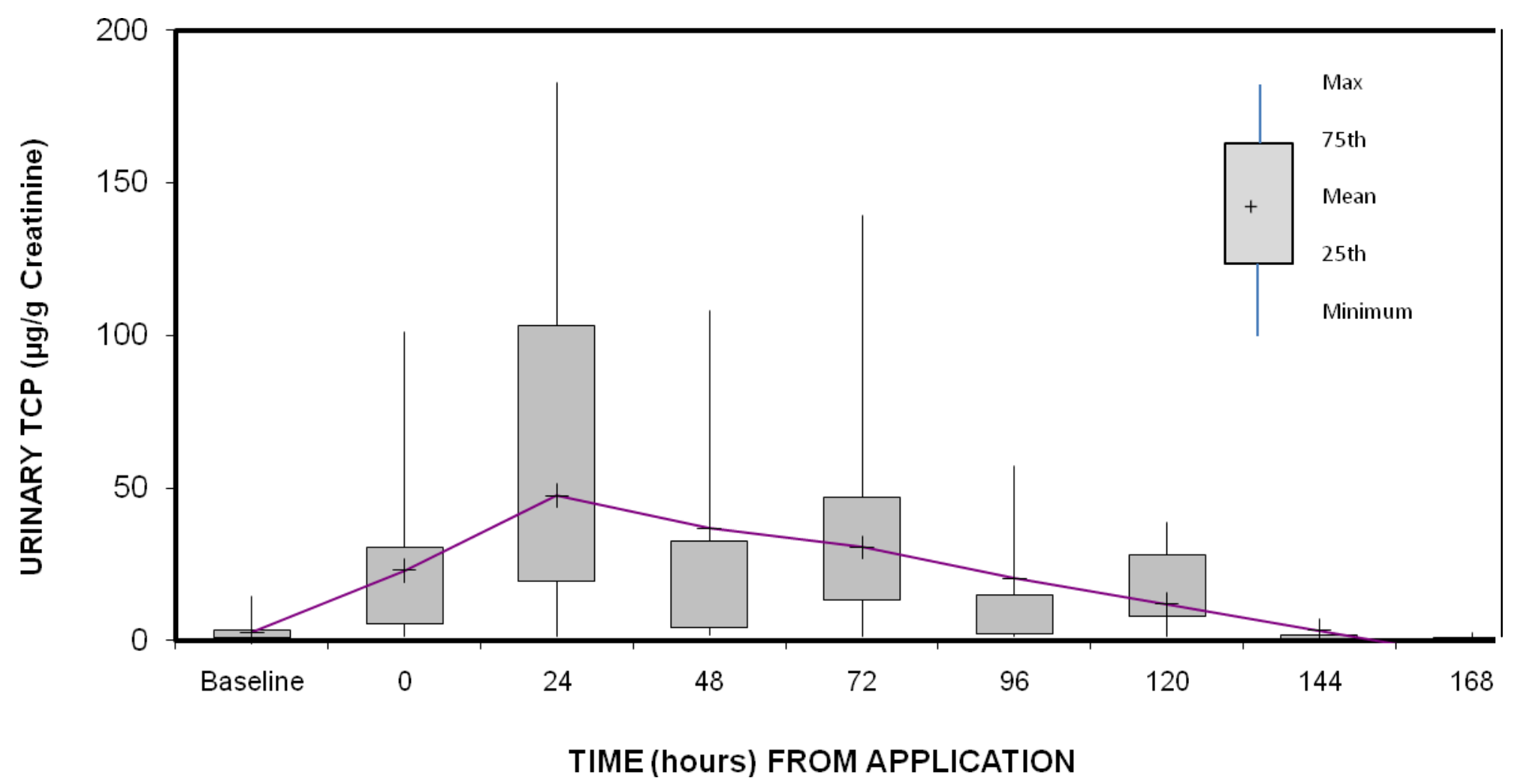

Fig.3. Urinary TCP levels as related to pesticide application time 


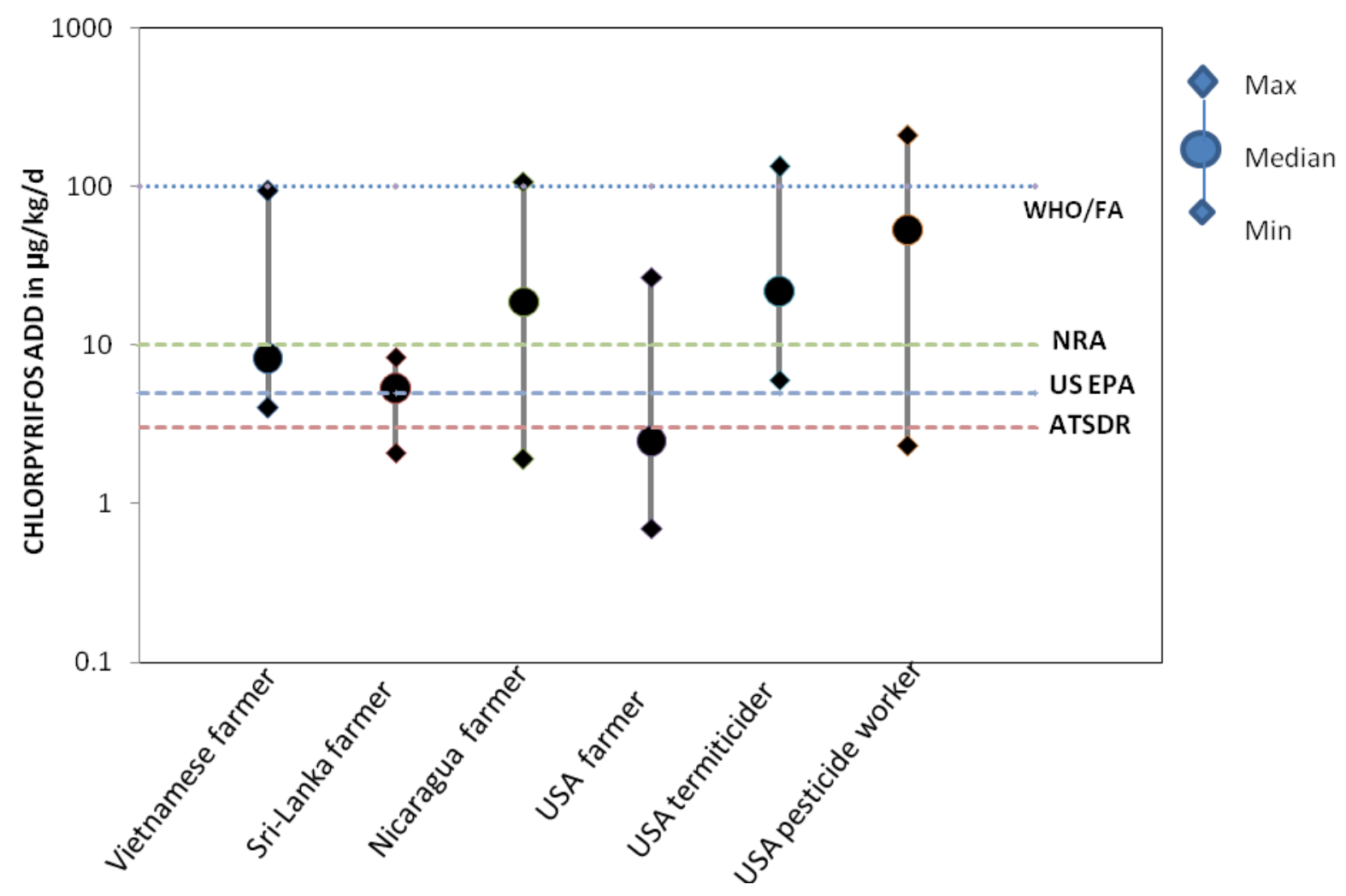

Fig.4. Comparison of ADD of pesticide applicators with guidelines for chlorpyrifos acute doses recommended by various agencies 